\title{
FACTORS RELATED TO NEONATAL SEPSIS EVENTS IN \\ DR. H. MOCH. ANSARI SALEH HOSPITAL BANJARMASIN
}

\author{
Sheilla Merlyana*, Desilestia Dwi Salmarini ${ }^{1}$, Dewi Pusparani Sinambela ${ }^{1}$ \\ ${ }^{1}$ AKBID Sari Mulia Banjarmasin \\ * E-mail: sheilla.merlyana1404@gmail.com
}

\begin{abstract}
Objective: This research aims at analyzing what factors related to the incidence of neonatal sepsis at Dr. H. Moch. Ansari Saleh Hospital, Banjarmasin in 2016

Method: A case-control study conducted on 8 to 15 April 2017 in dr. H. Moch. Ansari Saleh Banjarmasin. The population is divided into case population and control population. The study was conducted on 110 infants using a large ratio of 1:1 samples, divided into 55 infants with neonatorum sepsis (cases) with total sampling technique and 55 infants did not have neonatal sepsis (control) with simple random sampling technique. The data is taken with the instrument in the form of a checklist, then analyzed using Chi-Square test.

Results: The results showed that between maternal age and incidence of neonatal sepsis $\mathrm{p}=0.416$, gestational age and incidence of neonatal sepsis $\mathrm{p}=0,558$, type of labor and incidence of neonatal sepsis $p=0,004$, premature rupture of membrane with neonatorum sepsis $p=0,033$, BBLR and incidence of neonatal sepsis $\mathrm{p}=0.004$ and sex with incidence of neonatal sepsis $\mathrm{p}=0.039$.

Conclusion: There was no significant relationship between maternal age and gestational age with neonatal sepsis occurrence, there was a significant relationship between the type of labor, premature rupture of membranes, LBW, sex with neonatal sepsis occurrence.
\end{abstract}

Keywords: LBW, Gender, Type of Birth, Premature Rupture of Fever, Neonatal Sepsis, Pregnancy Age, Mother Age 


\section{INTRODUCTION}

Neonatal sepsis is a systemic infection caused by various microorganisms such as gram-positive or negative bacteria, viruses, parasites, and fungi. Neonatal sepsis can be distinguished from early-onset neonatal sepsis in neonates $<72$ hours, and slow onset in neonates aged $>72$ hours [1].

Neonatal sepsis is an important cause of morbidity and mortality among neonates and accounts for $30-50 \%$ of total neonatal deaths in developing countries [2]

The World Health Organization (WHO) data show that of the 5.9 million deaths in toddlers that occur in 2015, about half are caused by diseases and conditions such as pneumonia (17\%), complications of preterm birth (16\%), neonatal complications intrapartum $(11 \%)$, diarrhea $(8 \%)$, neonatal sepsis (7\%) and malaria (5\%) [3].

According to Profile of South Kalimantan Provincial Health Office Infant Mortality Rate (IMR) in 2011 infant mortality recorded as many as 77 cases, in 2012 as many as 67 cases, in 2013 as many as 84 cases, from the data seen an increase in infant mortality every year. The most causes of infant mortality are low birth weight (LBW), prematurity (premature birth) and asphyxia (spontaneous failure of breath and infection / sepsis [4].

In theory, risk factors associated with neonatal sepsis events are maternal factors such as infection and complications that occur during pregnancy such as TORCH, eclampsia, diabetes mellitus, congenital diseases, meconium mixed amniotic fluid, vaginal delivery (vacuum / cunam extraction, cesarean section), premature rupture of membranes, prolonged labor, fever, and maternal age. Then infant factors such as birth trauma, prematurity, lack of fluids and calories, hypothermia, male sex, and twins [5].

Data obtained from Medical Record RSUD Dr. H. Moch Ansari Saleh Banjarmasin stated that the incidence of Sepsis Neonatorum in 2014 was 83 babies (2.90\%) per 2861 newborns, by 2015 there was a decrease of 35 (1.22\%) of infants born with sepsis of 2876 infants newborn and in 2016 although the percentage of births with sepsis again decreased as much as $1.21 \%$, the number of babies who experienced asphyxia increased as many as 55 babies from 4516 newborns. Therefore, the incidence of sepsis in RSUD Dr. H. Moch Ansari Saleh Banjarmasin is still said to be quite high.

From the above data, it is clear that neonatal sepsis is still one of the dominant causes of infant mortality. Infant mortality with sepsis is not yet known what factors are likely to lead to it so that researchers are interested to examine the "Factor Factors Associated With Genomic Sepsis Occurrence At Dr. H. Moch Ansari Saleh Banjarmasin Year 2016 ".

\section{METHODS}

The location of this research is RSUD. Dr. H. Moch Ansari Saleh Banjarmasin. 
Target in this study were all newborns diagnosed with neonatal sepsis. The method used in this research is an analytic survey with case-control approach.

The population in this study were all newborn babies amounted to 4516 babies that was obtained infants who have neonatorum sepsis (population case) as many as 55 and infants who did not have sepsis neonatorum (control population) as much as 4461 . The sample in this study is divided into case and control samples with a large ratio of 1: 1 samples. Samples in the case group were 55 babies using total sampling technique or saturated sampling. The sample in the control group was 4461 babies using simple random sampling technique, that is by giving the lottery number 1 until 4461 then take randomly until it fulfilled the control sample of 55 people.

The research instrument used in this research is the baby room registration book RSUD Dr. H. Moch. Ansari Saleh Banjarmasin. Data analysis using chi-square statistic test with computerization aid.

\section{RESULTS}

1. Analyses of Univariate and Bivariate

a. Correlation between the mothers' ages and Neonatorum sepsis cases

\begin{tabular}{|c|c|c|c|c|c|c|}
\hline $\begin{array}{l}\mathrm{Cc} \\
\text { ne }\end{array}$ & $\begin{array}{l}\text { atio } \\
\text { toru }\end{array}$ & $\begin{array}{l}\text { betwe } \\
\text { sepsis }\end{array}$ & & $\begin{array}{l}\text { mothe } \\
2016\end{array}$ & , a & and \\
\hline \multirow{2}{*}{ Ages } & \multicolumn{2}{|c|}{ Cases } & \multicolumn{2}{|c|}{ Control } & \multicolumn{2}{|c|}{ Number } \\
\hline & $\mathrm{n}$ & $\%$ & $\mathrm{~N}$ & $\%$ & $\mathrm{n}$ & $\%$ \\
\hline At risk & 35 & 63,6 & 39 & 70,9 & 74 & 67,3 \\
\hline Not at risk & 20 & 36,4 & 16 & 29,1 & 36 & 32,7 \\
\hline Total & 55 & 100 & 55 & 100 & 110 & 100 \\
\hline
\end{tabular}

Table 1 shows that mothers with risky age in the case group accounted for 35 people (63.6\%), whereas in the control group, those with a risk age were 39 (70.9\%). Chi-Square test shows that $p=0,416$ hence $p>\alpha$ mean do not show any significant relation between maternal age with the incidence of neonatal sepsis in 2016.

The value of OR (Odds Ratio) is 0.718 (0.323 - 1.598). This suggests that although maternal age has no association with neonatal sepsis, mothers with $<20$ years or $>35$ years are at risk of 0.718 times having neonatal sepsis compared to mothers of 20-35 years of age.

Correlation between gestational age and neonatorum sepsis case

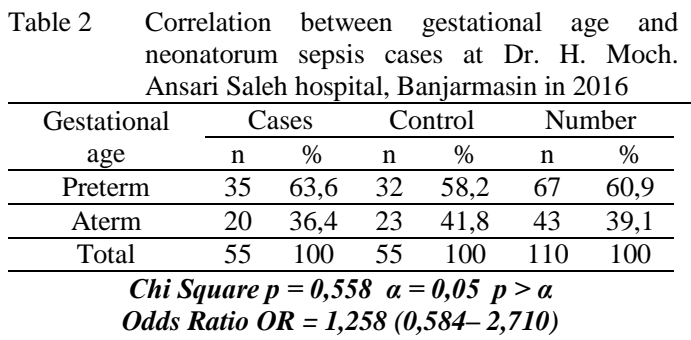

Table 2 states that respondents who have a preterm birth in the case group numbered 35 people $(63.6 \%)$, whereas, in the control group, those with preterm pregnancy were $32(58.2 \%)$. Chi-Square test shows that $p=0,558$ hence $p>\alpha$ mean do not show any significant correlation between age of pregnancy with an incidence of neonatal sepsis.

An OR (Odds Ratio) value of 1.258 (0.584 - 2.710) was obtained. This suggests that although the gestational age is unrelated to the incidence of neonatal sepsis, women who 
deliver with preterm delivery are at risk of 1,258 times having neonatal sepsis compared to mothers who gave birth to term pregnancy.

Table 3 shows the relationship of Type of Labor to Genomic Neonatal Sepsis at H. Moch. Ansaru Saleh hospital in Banjarmasin in 2016

\begin{tabular}{ccccccc}
\hline Types of & \multicolumn{2}{c}{ Cases } & \multicolumn{2}{c}{ Control } & \multicolumn{2}{c}{ Number } \\
\cline { 2 - 7 } labor & $\mathrm{n}$ & $\%$ & $\mathrm{n}$ & $\%$ & $\mathrm{n}$ & $\%$ \\
\hline Normal & 32 & 58,2 & 17 & 30,9 & 49 & 44,5 \\
\hline $\begin{array}{c}\text { Cesarean } \\
\text { section }\end{array}$ & 23 & 41,8 & 38 & 69,1 & 61 & 55,5 \\
\hline Total & 55 & 100 & 55 & 100 & 110 & 100 \\
\hline \multicolumn{4}{c}{ Chi Square $\boldsymbol{p}=\mathbf{0 , 0 0 4} \boldsymbol{\alpha}=\mathbf{0 , 0 5} \boldsymbol{p}<\boldsymbol{\alpha}$} \\
Odds Ratio OR $=\mathbf{3 , 1 1 0}(\mathbf{1 , 4 2 0}-\mathbf{6 , 8 0 9})$
\end{tabular}

Table 3 shows that the respondents who chose the normal type of childbirth in the group of cases were 32 people (58.2\%), while in the control group, they chose the cesarean section of 38 people $(69.1 \%)$. Chi-Square test results show $\mathrm{p}=0.004$ then $\mathrm{p}<\alpha$ means showing a significant relationship between the type of labor with the incidence of neonatal sepsis in 2016.

An OR (Odds Ratio) value of 3,110 $(1,420-6,809)$ was obtained. This suggests that women who chose to give birth in the normal way had a risk of 3.110 times having neonatal sepsis compared to mothers who chose to deliver by cesarean section.

Table 4 shows the correlation between premature rupture of membranes and neonatorum sepsis cases at the hospital in 2016

\begin{tabular}{ccccccc}
\hline $\begin{array}{c}\text { Premature } \\
\text { rapture of } \\
\text { membranes }\end{array}$ & \multicolumn{2}{c}{ Cases } & \multicolumn{2}{c}{ Control } & \multicolumn{2}{c}{ Number } \\
\cline { 2 - 7 } & $\mathrm{n}$ & $\%$ & $\mathrm{n}$ & $\%$ & $\mathrm{n}$ & $\%$ \\
\hline Yes & 28 & 50,9 & 17 & 30,9 & 45 & 40,9 \\
\hline No & 27 & 49,1 & 38 & 69,1 & 65 & 59,1 \\
\hline Total & 55 & 100 & 55 & 100 & 110 & 100 \\
\hline \multicolumn{6}{c}{ Chi Square $\boldsymbol{p}=\mathbf{0 , 0 3 3} \boldsymbol{\alpha}=\mathbf{0 , 0 5} \boldsymbol{p}<\boldsymbol{\alpha}$} \\
\hline \multicolumn{3}{c}{ Odds Ratio OR $\mathbf{2 , 3 1 8}(\mathbf{1 , 0 6 4}-\mathbf{5 , 0 5 1 )}$}
\end{tabular}

Table 4 identified the number of respondents who experienced premature rupture of membranes during delivery in the case group of 28 people (50.9\%), whereas in the control group, those who did not experience premature rupture of membranes during delivery were 38 (69.1\%). Chi-Square test results show $\mathrm{p}=0.033$ then $\mathrm{p}<\alpha$ means showing a meaningful relationship between premature rupture membrane with sepsis events.

An OR (Odds Ratio) value of 2.318 (1.064 - 5,051) was obtained. This suggests that women who experience premature rupture of membranes during delivery are 2.318 times more likely to have neonatal sepsis than women who do not experience premature rupture of membranes during delivery.

Table 5 presents the LBW relationship with Genesis Sepsis Neonatorum

\begin{tabular}{ccccccc}
\hline \multirow{2}{*}{ LBW } & \multicolumn{2}{c}{ Cases } & \multicolumn{2}{c}{ Control } & \multicolumn{2}{c}{ Numer } \\
\cline { 2 - 7 } & $\mathrm{n}$ & $\%$ & $\mathrm{n}$ & $\%$ & $\mathrm{n}$ & $\%$ \\
\hline Yes & 17 & 30,9 & 5 & 9,1 & 22 & 20 \\
\hline Not & 38 & 69,1 & 50 & 90,9 & 88 & 80 \\
\hline Total & 55 & 100 & 55 & 100 & 110 & 100 \\
\hline \multicolumn{6}{c}{ Chi Square $\boldsymbol{p}=\mathbf{0 , 0 0 4} \boldsymbol{\alpha}=\mathbf{0 , 0 5}$} & $\boldsymbol{p}<\boldsymbol{\alpha}$ \\
\hline \multicolumn{3}{c}{ Odds Ratio OR $\mathbf{4 , 4 7 4}(\mathbf{1 , 5 1 5}-\mathbf{1 3 , 2 0 9 )}$}
\end{tabular}

Table 5 shows that respondents who did not experience BBLR in the case group were 38 people (69.1\%), while in the control group the highest did not experience LBW as many as 50 people $(90.9 \%)$. Chi-Square test results show $\mathrm{p}=0.004$ then $\mathrm{p}<\alpha$ means showing a significant relationship between LBW with the incidence of neonatal sepsis.

The value of OR (Odds Ratio) of 4,474 $(1,515$ - 13,209) was obtained. This indicates that newborns who experience LBW risk 4.474 times experiencing sepsis neonatorum than newborns who do not experience LBW. 
Table 6 shows the relationship of Sex to Genesis of Neonatorum Sepsis

\begin{tabular}{ccccccc}
\hline \multirow{2}{*}{ Genders } & \multicolumn{2}{c}{ Cases } & \multicolumn{2}{c}{ Control } & \multicolumn{2}{c}{ Number } \\
\cline { 2 - 7 } & $\mathrm{n}$ & $\%$ & $\mathrm{n}$ & $\%$ & $\mathrm{n}$ & $\%$ \\
\hline Males & 43 & 78,2 & 33 & 60 & 76 & 69,1 \\
\hline Females & 12 & 21,8 & 22 & 40 & 34 & 30,9 \\
\hline Total & 55 & 100 & 55 & 100 & 110 & 100 \\
\hline Chi Square $\boldsymbol{p}=\mathbf{0 , 0 3 9} \boldsymbol{\alpha}=\mathbf{0 , 0 5} \boldsymbol{p}<\boldsymbol{\alpha}$ \\
\hline Odds Ratio $\boldsymbol{O R}=\mathbf{2 , 3 8 9}(\mathbf{1 , 0 3 4}-\mathbf{5 , 5 1 7 )}$
\end{tabular}

Odds Ratio OR = 2,389 $(1,034-5,517)$

Table 6 shows that male respondents in the case group numbered 43 people $(78.2 \%)$, while in the control group most were male (33\%) (60\%). Chi-Square test results showed $\mathrm{p}=0.039$ then $\mathrm{p}<\alpha$ means showing a significant relationship between sex with the incidence of neonatal sepsis.

An OR (Odds Ratio) value of 2.389 (1.034 - 5.517) was obtained. This suggests that newborns of the male sex are 2.389 times more likely to have neonatal sepsis than newborns of the female sex.

\section{DISCUSSION}

1. Correlation between the mothers' age and neonatorum sepsis cases

Chi-Square test shows that $\mathrm{p}=0,558$ hence $\mathrm{p}>\alpha$ mean do not show any significant correlation between age of pregnancy with an incidence of neonatal sepsis in RSUD Dr. H. Moch. Ansari Saleh Banjarmasin in 2016. This is in line with research which states that there is no significant relationship between maternal age with the incidence of neonatal sepsis $(P=0.111)[6]$.

2. Infants with the highest number of neonatal sepsis were infants born to risky maternal age, so expectant mothers of risky age were expected to perform antenatal care by consuming adequate nutrition and performing good and correct baby care and breastfeeding as early as possible in infants, so the incidence of neonatal sepsis can be avoided. In addition, pregnancy screening is also very important to do at least once in the first trimester, once in the second trimester and twice in the second trimester for the detection of high-risk and pregnancy complications. Maternal age is not the only factor that can cause neonatal sepsis but is multifactorial in that there are several factors that can cause neonatal sepsis.

3. Correlation between gestational age and neonatorum sepsis cases

Chi-Square test results show $\mathrm{p}=0,558$, then $\mathrm{p}>\alpha$ means do not show any significant relationship between age of pregnancy with an incidence of neonatal sepsis in RSUD Dr. H. Moch. Ansari Saleh Banjarmasin in 2016. This is in accordance with research conducted Nasution (2008) which states that the age of preterm pregnancy ( $<37$ weeks) cannot be concluded as a risk factor for neonatal sepsis [7].

This is also in line with the theory that infants born to mothers with gestational age, especially less than 37 weeks affect sepsis events, because passive transport of immunoglobulin begins at 8-12 weeks gestation past the placenta, entering the fetal circulation at 30-40 so that infants born at $<37$ weeks (premature) gestational age have immature immunity and are lacking IgG antibodies against certain bacteria, and 
premature infants are more susceptible to infection and are susceptible to infection or sepsis [8].

In contrast to the study which states that there is a significant relationship between gestation and the incidence of neonatal sepsis $(P=0.000)$. Gestational age is not the only factor that can cause neonatal sepsis but is multifactorial in that there are several factors that can cause neonatal sepsis [8].

Babies born to mothers with 37-42 weeks' gestation also did not rule out neonatal sepsis especially in developing countries such as Indonesia. Health services that have not been good, especially for mothers and neonates cause high rates of infection. Infection can be caused by a high intervention procedure in the infant from an early age so that it can be infected by germs in the delivery room.

4. Correlation between the type of labor and neonatorum sepsis cases

Based on the results of the study, it was found that most neonates who had neonatal sepsis were from the mother who chose the normal type of delivery as many as 32 people $(58.2 \%)$. This is inconsistent with the theory that infants born with more risky action occur in neonatal sepsis. This occurs because of germ contamination that occurs after birth, such as the tools used during labor delivery.

Statistical analysis with Chi-Square test yielded $\mathrm{p}$-value $=0,004$ and value $\alpha=0,05, \mathrm{p}$ $<\alpha$. Thus Ha accepted and H0 rejected which means there is a statistically significant relationship between the type of labor with the incidence of neonatal sepsis in RSUD Dr. H. Moch. Ansari Saleh Banjarmasin in 2016. This is because babies born with caesarean section do not experience spontaneous respiratory mechanisms as in normal delivery, but if they receive good care after birth, breastfeeding as early as possible, and observations are made before the treatment is done, occurs after cesarean section delivery may be detected as early as possible, so the incidence of neonatal sepsis may be prevented [6].

This is also consistent with research conducted by Lihawa [9] which states that there is a significant relationship between the type of labor and the incidence of neonatal sepsis $(\mathrm{P}=0.001) .8$ In contrast to research conducted on Risk Factors of Neonatorum Sepsis in the Perinatology Room at Sanglah Denpasar Public Hospital mentioning that the type of labor has nothing to do with the incidence of neonatal sepsis $(P=0.438)$ [10]

The act of labor is not the only factor that can cause sepsis in the neonate but is multifactorial and there are several factors that can cause sepsis, one of them from the nursing environment. The bacteria that cause sepsis usually come from the outside environment or hospital. In addition, the use of invasive tools and measures such as parenteral nutrition, percutaneous catheter installation, or mechanical ventilation can lead to bacterial transmission primarily to infected neonates [11]. 
5. Correlation between premature rupture of membranes and neonatorum sepsis cases

Chi-Square test results show $\mathrm{p}=0.033$ then $\mathrm{p}<\alpha$ means to indicate a significant relationship between premature rupture membrane with the incidence of neonatal sepsis in RSUD Dr. H. Moch. Ansari Saleh Banjarmasin in 2016. This is in accordance with Hasanah's [11] study which states that there is a significant relationship between premature rupture of membranes with neonatal sepsis $(P=0,000)$ and the risk of having 5 times greater neonatal sepsis $(\mathrm{OR}=$ $5,802)$.

This is in accordance with the theory that declared premature rupture of membranes (KPD) is a risk factor for neonatal sepsis, this can occur because KPD can increase pregnancy complications in mothers and infants, especially infections. For the fetus fewer months with KPD, the risk of having a lunar birth should be compared to the risk of infection and sepsis, whose presence in the womb, can even make it more problematic. The discovery of bacteria with gram staining or amnionic fluid cultures obtained in amniocentesis correlates with subsequent maternal infection in about 50 percent of cases and neonatal sepsis at about 25 percent.

\section{Correlation between LBW and neonatorum sepsis cases}

From the results of a large analysis of the risk of LBW to the incidence of neonatal sepsis, the value of OR (Odds Ratio) of 4.474 is obtained. This indicates that newborns who experience LBW risk 4.474 times experiencing sepsis neonatorum than newborns who do not experience LBW. This is consistent which states that there is a significant relationship between LBW and neonatal sepsis events $(\mathrm{P}=0.001)$ and has a risk of having 28 times greater neonatal sepsis $(\mathrm{OR}=28.4)[10]$.

This is in line with the theory that LBW babies are at risk for neonatal sepsis because in infants with LBW the maturation of the body organs (liver, lungs, digestion, brain, defense of the body against infection, etc.) is not perfect, so LBW infants often have complications that end in death [12].

Low birth weight babies have a chance of getting infected since the time of the womb. Intrauterine infections can cause impaired uteroplacental blood flow so that transport of various substances needed by the fetus, including immunoglobulin $\mathrm{G}$ ( $\mathrm{IgG})$, which plays a role in the baby's body's defense against bacterial infections, especially gram-negative organisms, bacterial toxins, and viruses early in life will be disrupted. ${ }^{11}$ This is why low birth weight babies are more susceptible to sepsis and are at high risk for poor prognosis [13].

7. Correlation between gender and neonatorum sepsis cases

Chi-Square test results show $\mathrm{p}=0.039$ then $\mathrm{p}<\alpha$ means showing a significant relationship between sex with the incidence of neonatal sepsis in RSUD Dr. H. Moch. Ansari Saleh Banjarmasin in 2016. This is in 
accordance with research conducted which shows that there is a relationship between sex with the incidence of neonatal sepsis $(\mathrm{P}=$ $0.007)$ and 3 times greater risk of neonatal sepsis compared with neonates of the sex female $(\mathrm{OR}=3,525)[11]$.

This is in line with the theory that men are a risk factor for neonatal sepsis and should be considered as risk factors for infection for each infant. The incidence of sepsis in males is four times greater than that of female infants is not known clearly but has been documented for more than a few decades. However, there are studies that suggest that neonatal infections are common in boys, 4 times greater than female infants because the genes on the $\mathrm{X}$ chromosome affect the function of the thymus gland and $\mathrm{lg}$ synthesis. Women have $2 \mathrm{X}$ chromosomes, this causes more resistance to infection.

Male and female infants if treated well especially for personal hygiene and adequate nutrition, and given early breastfeeding can boost immunity because of the immunoglobulin content in breast milk so that babies are not susceptible to infection during the neonatal period.

\section{REFERENCES}

[1]. Salendu Praevilia M. Sepsis neonatorum dan pneumonia pada bayi aterm. Jurnal Biomedik (Jbm). 4(3): 175-179. 2012.

[2]. Gandhy, et., al. Incidence of neonatal sepsis in tertiary care hospital: an overview. International Journal of
Medical Science And Public Health. 2(3):548. 2013.

[3]. World Health Organization (WHO). Trends in Maternal Mortality: 1990 to 2015. Geneva: World Health Organization. 2015.

[4]. Dinas Kesehatan Provinsi Kalimantan Selatan. Profil Kesehatan Provinsi Kalimantan Selatan 2013. Banjarmasin: Dinas Kesehatan Provinsi Kalimantan Selatan. 2014.

[5]. Simbolon, Demsa, Faktor risiko Sepsis pada bayi baru lahir di RSUP curup kabupaten rejang lebong. Jurnal Kesehatan. 36(3):127 - 134. 2008.

[6]. Yuliana, Fitri. Analisis faktor risiko kejadian sepsis neonatorum di RSUD Dr. H. Moch Ansari Saleh Banjarmasin tahun 2016. [Skripsi]. Jakarta. Universitas Respati. 2016.

[7]. Nasution Diapari Arisandi. Faktor risiko dan kesamaan jenis kuman jalan lahir ibu dengan kultur darah pada sepsis neonatal awitan dini [tesis]. Semarang: Universitas Diponegoro. 2008.

[8]. Dini, Fitri Nur. Hubungan antara masa gestasi dan kejadian sepsis neonatorum di rsud ulin banjarmasin periode juni 2014-juni 2015. Berkala Kedokteran. 12(2):175-185. 2015.

[9]. Lihawa, Maria Y., dkk. Hubungan jenis persalinan dengan kejadian sepsis neonatorum di RSUP Prof. Dr. R. D. Kandou Manado. Bagian Ilmu Kesehatan Anak Fakultas Kedokteran Universitas Sam Ratulangi Manado. 2013.

[10]. Widayati, Kurniasih, dkk. Faktor risiko sepsis neonatorum di ruang perinatologi rumah sakit umum pusat sanglah denpasar. Public Health and Preventive Medicine Archive. 4(1):85-93. 2015.

[11]. Hasanah, Nur Mukmin, dkk. Analisis faktor risiko jenis kelamin bayi, bblr, persalinan prematur, ketuban pecah dini dan tindakan persalinan dengan kejadian sepsis neonatus di rumah sakit bahteramas provinsi sulawesi tenggara tahun 2016. Fakultas Kesehatan Masyarakat Universitas Halu Oleo. 112. 2016. 
[12]. Carolus, dkk. Hubungan apgar skor dan berat badan lahir dengan sepsis neonatorum. Bagian Ilmu Kesehatan Anak Fakultas Kedokteran Universitas Sam Ratulangi Manado. 2013.

[13]. Leal Y, et.al. Risk factors and prognosis for neonatal sepsis in southeastern Mexico: analysis of four year historic cohort follow up. Journal BMC Pregnancy and Childbirth. 12(48). 2012. 